\title{
Aesthetics of Self-Scaling: Parallaxed Transregionalism and Kutluğ Ataman's Art-Practice
}

\section{Cüneyt Çakırlar}

[published in Critical Arts: South-North Cultural and Media Studies 27(6), Special Issue: Revisiting Ethnographic Turn in Contemporary Art 2, December 2013, pp. 684706. http://dx.doi.org/10.1080/02560046.2013.867591]

\begin{abstract}
:
This article examines relations of ethnography, contemporary art-practice, globalisation and scalar geopolitics with particular reference to Kutluğ Ataman's artworks. Having been shortlisted for the Turner Prize at the Tate and awarded the prestigious international Carnegie Prize in 2004 with his forty-screen video installation Küba (2004), Ataman became an extremely well-known, globally acclaimed artist and filmmaker. Self-conscious of their global travel and critically attentive to the contemporary ethnographic turn in the visual arts scene, Ataman's video-works perform a conscientious failure of representing cultural alterity as indigeneity. Concentrating on the artist's engagement with ethnography, this article contains three main parts. Analyses of the selection of videos in each part will give an account of different scalar aspects of Ataman's artworks. It will first revisit a previous study (Çakirlar 2011) on the artist's earlier work of video-portraits including Never My Soul! (2002) and Women Who Wear Wigs (1999). A detailed discussion of Küba follows, which may be taken as the 'hinge-work' in Ataman's oeuvre that marks a scalar transition in his critical focus - from body and identity to community and geopolitics. The discussion will then move to a brief analysis of the series Mesopotamian Dramaturgies, including the screen-based sculptures Dome (2009), Column (2009), Frame (2009), English as a Second Language (2009), and The Complete Works of William Shakespeare (2009). Rather than addressing scale as a differential concept, this article aims to demonstrate the ways in which Ataman's artpractice produces self-scaling, self-regioning subjects that unsettle the hierarchical constructions of scale and facilitates a critique of the scalar normativity within the global art world's regionalisms and internationalisms.
\end{abstract}

Keywords: scale, ethnography, documentary, Ataman, Turkey, globalization

Cüneyt Çakirlar is Lecturer in Communications, Culture and Media Studies, Nottingham Trent University, UK. cuneyt.cakirlar@,ntu.ac.uk 


\section{Aesthetics of Self-Scaling: \\ Parallaxed Transregionalism and Kutluğ Ataman's Art-Practice ${ }^{1}$}

\section{Cüneyt Çakırlar}

[published in Critical Arts: South-North Cultural and Media Studies 27(6), Special

Issue: Revisiting Ethnographic Turn in Contemporary Art 2, December 2013, pp. 684-

706. http://dx.doi.org/10.1080/02560046.2013.867591]

Born in Istanbul in 1961, Kutluğ Ataman can be considered one of the most internationally well-known video artists in the global contemporary art scene. Having trained as a filmmaker in Los Angeles and worked and lived in London, Istanbul, Barcelona and Buenos Aires, Ataman was a travelling artist from the very early stages of his career. Since his first (controversial) appearance in the international art market in 1997, the artist has contributed to major biennials and his artworks are now in major international collections including the Carnegie Museum, Museum of Modern Art and Tate Modern. Incorporating his background of filmmaking with his art practice in various innovative ways and translating his cinematic vision to the medium of video installation through sculptural forms of talking heads filmed in conversation, Ataman's art-practice has been regarded as symptomatic of 'the twin phenomena of the globalized art world's embrace of a non-Western artist and its simultaneous embrace of documentary' (Lebow 2008: 58). Self-aware of its global reach and critically responsive to the ethnographic turn(s) in the contemporary art market, the artist's practice, I would argue, facilitates new possibilities in art criticism in terms of scales of analysis, and scalar constructions of regionality, authorship, aesthetics and ethnography.

This article thus aims to discuss a selection of the artist's art works in concentrating on his playful formal engagement with constructions of culture, history, geography and globalisation. The discussion will explore Ataman's enactment of a critical transregionalism where region-as-concept becomes a 'dramaturgy' of power and discourse, and the ethnographic gaze constantly confronts the conflict between intricate non-Western articulations of modernity and Western ideals of form, medium, genre in representing such alterity. The artworks Küba (2004) and Paradise (2006) can be taken here as a turnover point in Ataman's career where his project of individual life-stories, or portraits via long streams of talk, unsettling its own documentary ethnographic setting or mapping, shifts its focus to a revised crosscultural aesthetic of queering ideological narratives of geography, history and community. While there is a scalar diversity throughout Ataman's oeuvre, his methodology allows each individual art-work to bear, if not perform, a critical statement on the performative politics of scaling by unsettling the normative distinctions of scalar thinking. This article thus speculates on the ways in which Ataman's ethnographic accent materialises and reappropriates scale as a structuring norm 'by which capital negotiates its own contradictions' through the divisions between the bodily, the national, the regional and the global (Herod 2011: 9). In treating the notion of scale topologically rather than topographically, "not as areal units but as parts of networks' (ibid: 23), this discussion will be presented in three main parts, each of which analyses a selection of videos and gives an account of

\footnotetext{
${ }^{1}$ For a detailed archive of Kutluğ Ataman's art works, please see the artist's offical web page: http://www.saatleriayarlamaenstitusu.com/site/main
} 
different scalar aspects of Ataman's artworks. The first section revisits a previous study I conducted (2011) on the artist's earlier work of video-portraits that documents self-performance to reveal the fictional status of subjectivity. The second section offers a detailed discussion of Küba, which might be considered the 'hinge-work' in Ataman's oeuvre marking a scalar transition in his critical focus - from body and identity to community and geopolitics. A brief analysis of the series Mesopotamian Dramaturgies follows, including the screen-based sculptures Dome (2009), Column (2009), Frame (2009), English as a Second Language (2009) and The Complete Works of William Shakespeare (2009) - to discuss the artist's critical gesture to the ways in which history and geography is being mediated in arts.

What is dramatically at play in Ataman's Mesopotamian Dramaturgies is that the artist appropriates and questions modes of aesthetic intelligibility in Western artpractice to represent the other: documentary, ethnography, photography, film/video, the Renaissance painting, frescos, domes and columns. I would also argue that these later artworks bear a retrospective effect in enabling the critic to re-frame and re-scale the artist's earlier practice. In his later series, Ataman strategically instrumentalises contemporary art media as cultural capital, and uses Mesopotamia performatively as a critical region of cultural alterity exposed to global and regional forms of conflict, power and violence. In doing so, the artist enacts a travelling art-practice that questions conventions of travel and translation in global/ised contemporary art scene, and explores possibilities of a non-assimilating spectatorial and authorial encounter. This approach aligns with Hal Foster's (1996) critical questioning of the contemporary figure of 'the artist as ethnographer'. Discussing contemporary art's relation to cultural alterity, Foster proposes a 'parallactic work that attempts to frame the framer as he or she frames the other' in order to eliminate 'ideological patronage,' or, a 'reductive over-identification with' and 'a murderous disidentification from' the other (1996: 203). In parallel, Ataman's self-framing, self-regioning aesthetics addresses the global art consumer by 'contesting and queering the dominant narratives of globalisation and ... the art world's fascination with difference mediated through documentary' (Nash 2005: 47). In short, what particularly interests me here is the extent to which Ataman's ethnographic 'eye' or method demonstrates, in James Clifford's (2001: 56) words, 'a willingness to be decentred in acts of translation.'

From its early stages, Ataman's art-practice 'problematizes ethnography as method and documentary as genre' (Çakirlar 2011, the author's emphasis). Extrapolating the self-reflexive aesthetic agenda of cinéma vérité to the medium of video art, Ataman presents his subjects as busily constructing themselves in front of the camera, via talk and self-performance, where the artist's strategically unmarked authority reveals a critical ambiguity in terms of agency, identity and identification. Self-conscious of their international travel and critically attentive to the art world's politics of culturalism, alterity and indigeneity, Ataman's video-works perform 'a conscientious failure' (Çakirlar 2011) of representing cultural alterity as indigeneity. Such aesthetics of failure, I contend, renders visible the scalar implications of Foster's critique of the ethnographic turn. The 'self-framing' which Foster proposes in what he terms as a possible 'parallactic work' seems to inevitably expect, from the 'artist-asethnographer', a multiscalar consciousness that reflects on the productions and constructions of scale within the mechanism by which contemporary art's so-called internationalism produces simultaneously the (local) other and the (global) political. 


\section{Alterity, Regionality, Scale}

Having been shortlisted for the Turner Prize at the Tate and awarded the prestigious international Carnegie Prize in 2004 with his forty-screen video installation, Küba (2004), Ataman became an extremely well-known, globally acclaimed artist and filmmaker. While this recognition demonstrates that Ataman's work offers resonances that encompass Euro-American contemporary art scenes, his art practice had implicated complex layers of a critical self-reflexivity questioning its own translation and inter-regional travel. In Ataman's works, the regional/national index confronts the global in that the deliberate failure of documentary address reciprocates the spectatorial experience, and the very problem of scaling and translation is narrativised rather than being resolved. The artist's early project, summarily, had been 'to document, through catalysis, the constitutive performative excess within which the subject constantly fictionalizes, realizes and undoes his/her own self across time and space' (Çakirlar 2011). Within the pseudo-ethnographic framework of his screenbased multi-channel video installations, reality and fiction is made to collide while the conversations on screen reveal intimate life stories (or storytellings) and demands from the viewer the reciprocation of this narrative intimacy. Ataman incorporates 'a politically self-conscious distance, both intimate and impersonal, vis-à-vis the subject of (re-)presentation' (2011: 359): addressing an erotic of impersonality and the impossibility of intimacy, from within an intimate visual setting, he attempts to confront the viewer with the machinery of truth-making and self-invention. Such a critical investment in fiction also bears a crucial political implication in the global art scene: the departure from a conventional documentary project - of 'documenting victims [from non-western regions of conflict]' - and the 'rejection of the inequality of representational divisions [fiction/documentary]' triggers an intervention of 'claiming access to fiction as [an artist marked non-western]' (Demos 2013: 197). This 'claim to fiction,' TJ Demos discusses in the context of Lebanese artists such as Mroué, Raad and Zaatari, 'has the effect of derealizing the documentary evidence ... on which the dominant power draws its justifications and rationales' and thus 'reorganize[s] the roles and competences of those who represent reality' (ibid: 197-8).

According to Irit Rogoff (2009: 172, 166), the aesthetic rigour in Ataman's work 'undo[es] ... the stereotyped banalities that package non-Western cultures for Western consumption ... [in] producing narratives and subjects in the world that did not preexist it.' In other words, the ethnographic framework in these 'talking pieces' expands from voices of particular regions to a narration of experience which cannot easily be categorised through geographical markers of identity and identification. The medium, the installation form and the narration of the performative documentary aesthetic in Ataman's practice implicates an address that constantly questions, in diversifying, the scale and the regionality of the experiences on screen. The subjects are not presented as passive recipients of local state ideologies or of global imperatives in documeting alterity. 'The Turkey in Ataman's work,' Rogoff says, 'expands internally rather than being bounded from outside and kept at bay' (2009: 168, my emphasis). Nationality, or regionality, becomes a performative supplement rather than a scalar index, which provides Ataman's work with a critical affinity that 'explores the limits of documentary practice and complicates the ethnographic paradigm with which so many artists, galleries and institutions are [still] currently preoccupied' (Nash 2005: 42). This 'internal expansion' has, indeed, scalar implications and may be considered a response to 'the parallactic' in Foster's critique, 
as such self-reflexivity of the ethnographer bears the potential of constructing a versatile textuality constantly self-altering in its scalar subject where 'globalness and localness are not inherent[ly differential] qualities of an object [but] interpretive frames [or] scales of analysis' (Gibson-Graham 2002: 30).

My previous study on Ataman's earlier works, particularly Never My Soul! (2001), suggested a critical re-enactment of what the artist termed his 'parallax view' as my methodology (Honigman 2004: 86; Anton 2003: 116; Çakirlar 2011). My discussion oscillated constantly between localising and universalising/globalising discourses in contemporary art criticism to explore 'the ways in which the critical potentials of the artwork might operate both within and beyond its national referent' (Çakırlar 2011: 361). For instance, in Never My Soul! (2001), Ataman's play with Yeşilçam melodrama, camp, pornography and documentary realism as genres implicates a localised or hybridised accent while the formal/curatorial arrangement of the piece along with the performative use of video-as-medium, montage, and ethnography addresses the global contemporary art market. As in Never My Soul!, most of Ataman's videos bear a textual (as well as scalar) versatility and thus complicate the surface/depth binary: these artworks operate within a 'zone of intersection where what queer aesthetics valorizes as surface and what neo-Marxist critiques of globalization (and/or) postmodernism devalorizes as flat or flattening overlap and transfigure each other' (Çakirlar 2011). What I had only implied previously but had not had the opportunity to unpack is the abstraction of scale dramatically at work in Ataman's artpractice. This offers resonances with what Marylin Strathern's (2004: xvi) ethnographic method terms a 'postplural perception of the world'. In Strathern's methodological framework, 'things act as their own scales [and] ... scales can be said to originate in the things they serve to compare' (Holbraad and Pedersen 2008: 375-8, the authors' emphasis). Ataman's practice bends the scalar politics of the global in complicating hierarchies and distinctions between the body, the national and the global.

Correspondingly, I take Ataman's art as a theoretical object itself, as an image of thought that actively theorises and scales itself. In enacting such self-scaling, it demands a multiscalar response from the critical interlocutor: the spectator and the art critic. Thus my analysis of Never My Soul! sought a possible critical mode of what Rogoff conceptualises as 'regional imaginings':

an alternative, non-identitarian practice, a practice that does not feel obliged to root one exclusively in either material histories or in purely fantastical projections, opting instead to piece together a location from fragments of what was and of what might be, simultaneously; an attempt both to activate and to actualize notions of location away from being 'located' by an authority of knowledge or a political authority (being Turkish, being Middle Eastern, being of the Muslim world, for example) and towards a notion of '(self)-regioning' ... which focuses not on trying to figure out what one's identity might be as a given, but on trying to produce a set of relationships in the world that might locate one (Rogoff 2010: 48).

In its entirety, Ataman's practice is paradigmatic of a 'self-regioning' critical mode that 'makes possible other forms of territorial affinity rather than belonging' (Rogoff 2010: 54). While the multitude of voices, if not cacophony, in his artworks suggests a 
critical engagement with difference and with possibilities of scaling (or locating and regionalising) difference, each character or community or region in these artworks challenges a unitary identity as well as a fixed spatial address or scale. Ataman's works do not only cover various scales of self and location but also challenge the boundaries between geographical levels of scale: the bodily, the communal, the urban, the national, the regional, the continental and the global are presented as inevitably constitutive of each other. The performance of an eighty-seven-year-old Turkish diva Semiha Berksoy in semiha b. unplugged (1997), the narration of redoubled speech in the Turkish-Cypriot woman Neşe Yaşın's testimonies in $1+1=1$ (2002), the allegoric community that the four women in Women Who Wear Wigs (1999) form in using wigs as an instrument for gender dissidence, the 'impossible' communities of Küba (2004) and Paradise (2006), and finally, the monumentalised residents of Eastern Anatolia quietly looking at the Western art consumer in Column (2009) along with the Anatolian youth reading Shakespeare in English to the art enthusiast in English as a Foreign Language (2009) are examples of Ataman's subjects. Such mobility of scales comes from the critical dialogue the artist constructs between the medial aesthetics of video art (and its affinities with film, sculpture, and photography) and the regional elements of the narrative. Hence, what makes Ataman's project interesting for the global art world is not - primarily - the western primitivist fantasy of the exotic Turkey, but the ways in which the artist grounds regions (especially Turkey) and how bodies are presented to inhabit these regions. This 'grounding,' I would argue, takes place through a prioritised address at aesthetics in Ataman's art practice. In other words, an aesthetic value is being attached to these inhabitations: life becomes storytelling, construction, a series of truthful lies, or put simply, art.

Duration, narrative parallaxing, and the sculptural mode of installation form are the key aesthetic components of Ataman's artworks, which catalyzes the artist's critical engagement with the documentary/ethnographic other. For instance, the nearly eighthour performance of the eighty-seven-year-old Turkish opera diva Semiha Berksoy in semiha b. unplugged (1997) (Fig. 1) invites the viewer to a portrait-in-drag where Berksoy's house becomes a phantasmatic setting, a dwelling of her 'clumsy' hyperbolic enactment of remembering the early years of modern republican Turkey. However, Ataman's montage as well as 'the length of the piece', as Mark Nash suggests (2005: 44), 'means that the viewer is both immersed in and overwhelmed by, indeed loses control of, the material they are being presented with.' Along with what TJ Demos (2010) terms as Ataman's 'metamorphic montage' which connects contradictory aspects of one's own narration of identity and history, the duration of the artwork becomes a statement about art, about Berksoy's performance as an allegory of art. 


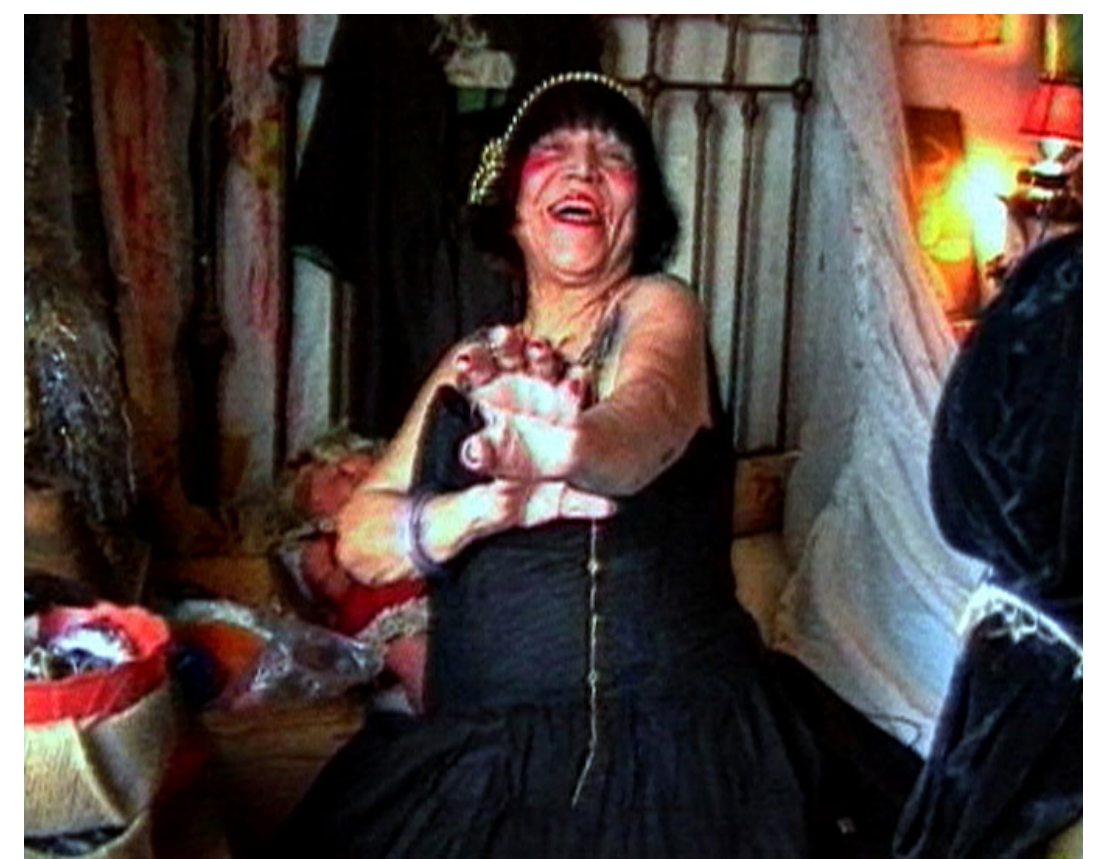

Fig. 1: Kutluğ Ataman, semiha b. unplugged, 1997. Single-screen video installation. Courtesy of the artist and Thomas Dane Gallery, London. Reproduced with permission.

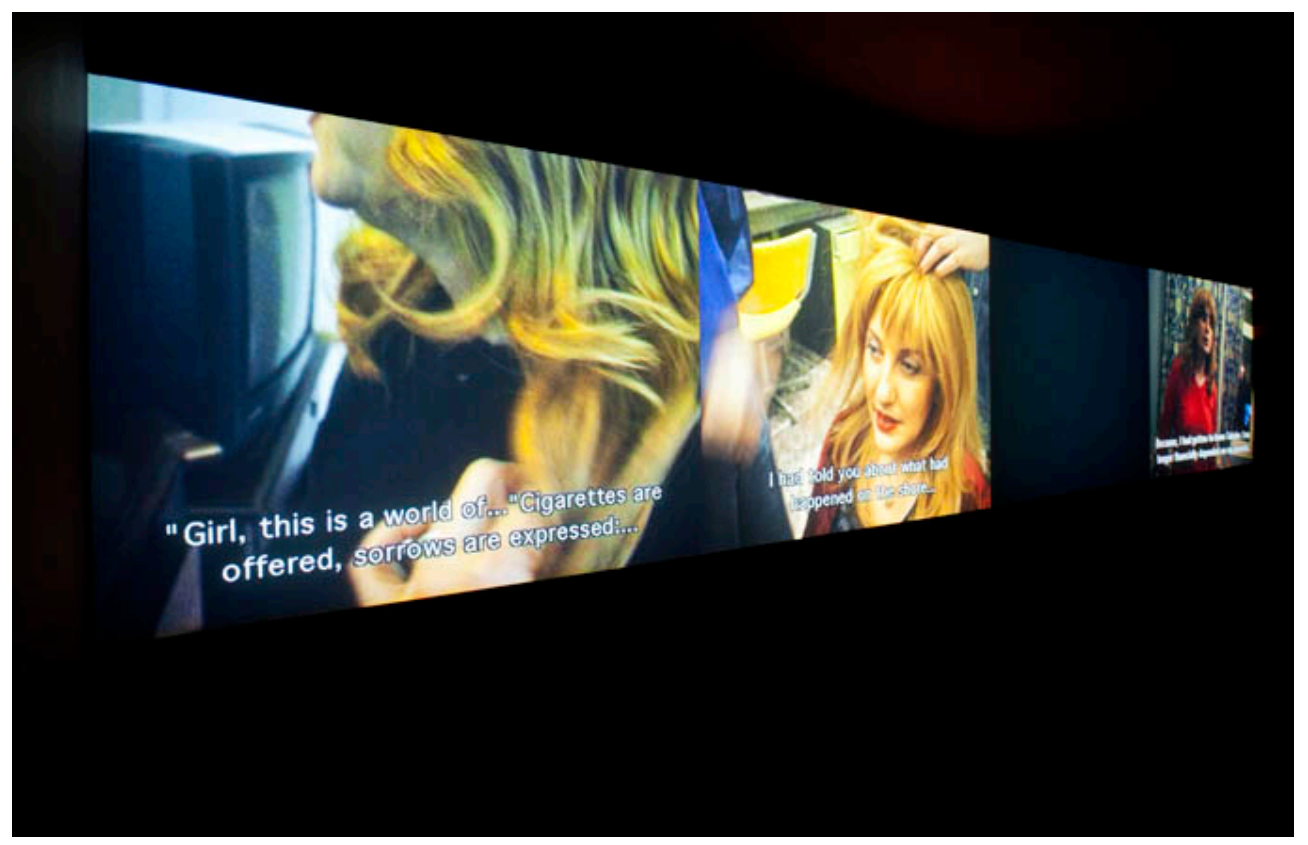

Fig. 2: Kutluğ Ataman, Women Who Wear Wigs, 1999. Multi-screen video installation. Courtesy of the artist and Thomas Dane Gallery, London. Reproduced with permission.

Moreover, the four adjacent screens with simultaneously looping conversations in Women Who Wear Wigs (1999) (Fig. 2) do not only reveal the oral-visual cacophony of the four Turkish women (each with radically different reasons for wearing wigs: a balding transsexual, an ex-revolutionary, a Muslim student, and a cancer patient under treatment) but also offers indefinite possibilities for spectatorial experience. The lengths of the looping videos are different from each other, which produces different snapshots of the four-screen installation throughout the flow of videos: the women encounter each other anew and the viewer is constantly being addressed by this dynamic video-sculpture. This implies an intermedial experimentation with an 'oral 
visuality' (Gade 2003: 6) whose aesthetics expands geographical locations and calls for a complex form of transregional relationality in contemporary arts: what matters here is how subjects relate to regions by locating themselves differently and creatively (Rogoff 2010: 48; 2000), and how an artistic practice would possibly create the possibility for the viewer to experience a decolonised ethnographic setting in which subjects actively talk about their lives that inhabit 'spaces that exist in tangential relation to the nation but that are simultaneously and irreducibly marked by complex national and global processes' (Gopinath 2008: 343). They are 'self-regioning' actors and Ataman's aesthetic discourse constructs an 'impersonal intimacy' where alterity is constructed through not a unitary margin, nor an 'anthropological insight' but a parallaxed 'portrayal of affective speech' (Demos 2010: 34).

By subjecting the audience to feel 'overwhelmed by the interview monologues presented not in series (as in a single-screen film or video) but in parallel simultaneously,' Nash states (2005:43), 'the issue of choice is returned to the audience ... almost aggressively'. The viewer's body is invited to create her/his own narrative through the exposure to the four parallel testimonies of life in Women Who Wear Wigs, the characters' truth-bending narrative-in-drag in semiha or Never My Soul! (where scripted and un-scripted conversations of the transgendered character Ceyhan are intercut), or the revelation of the Turkish-Cypriot woman Neşe Yaşın's 'divided self' in $l+1=1$ (2002) (Fig. 3) where the subjectivity 'partitioned' by state narratives of nation is reenacted by two hinged screens that face each other. As Demos also suggests (2010: 34), 'speech - and film in turn' in the artist's imagery operates in various levels of parallel narrative surfaces undoing or transfiguring each other, and becomes 'a self-differentiating vehicle'.

In ethnographic terms, then, scale is continuously shifting in Ataman's playful aesthetic universe - from bodies that speech unfolds to nation-states and global flows that incite the subject to identity; from the regional to the global, both of which the artist's camera accommodates and distantiates from. This offers connections with what Strathern proposes as 'post-plural abstraction of scale': according to Holbraad and Petersen, comparison here as concept and practice,

is no longer a matter of identifying the general scales that may act as "common denominators" that relate things; [it is] rather oriented towards revealing "uncommon denominators," if by that one means the peculiar and highly specific capacities for transformation that things(-cum-scales) hold so contingently within themselves. (Holbraad and Petersen 2009: 382).

The comparative aesthetics in Women Who Wear Wigs, for instance, enacts a selfscaling: it explores the conventional scalar units (the bodily, the national, and the global) but cannot be reduced to them. Wig-as-concept abstracts these scales and operates as the art-work's own scalar unit. 


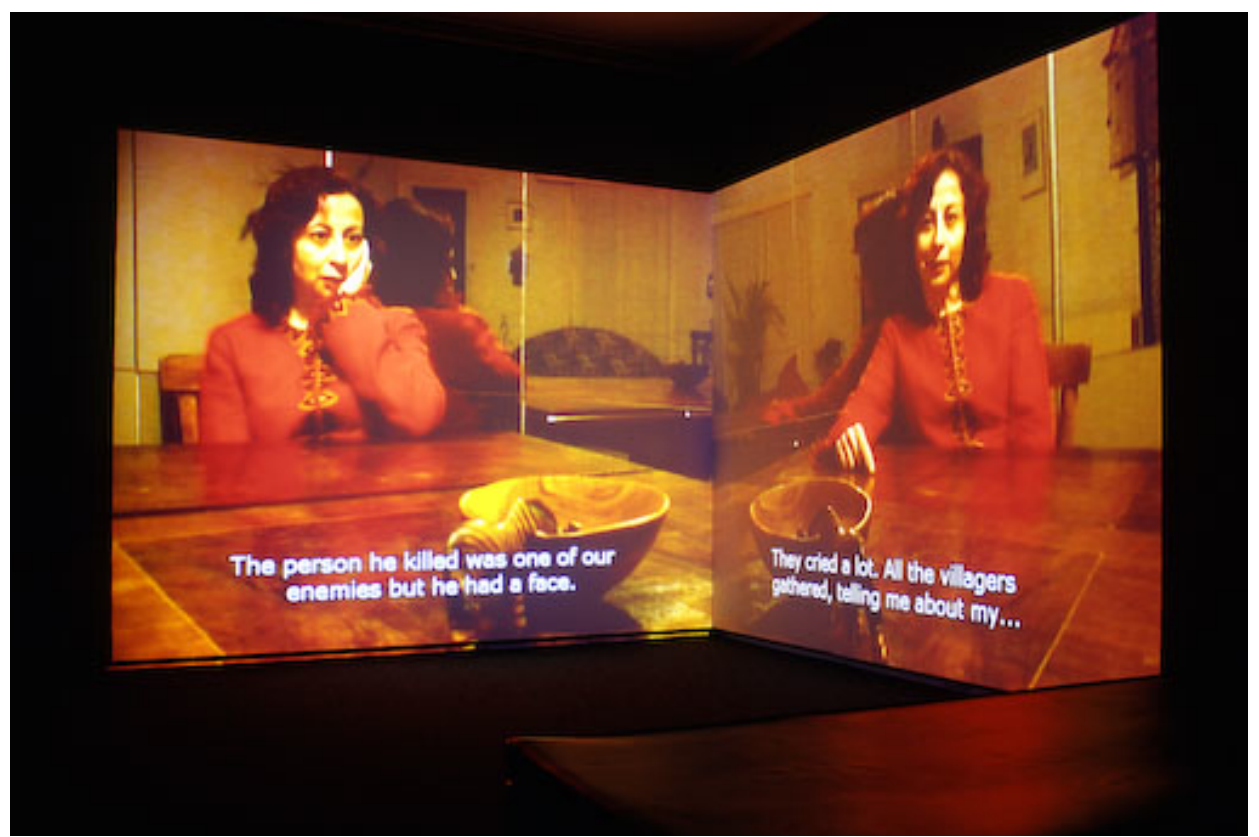

Fig. 3: Kutluğ Ataman, $1+1=1,2002$. Two-screen video installation.

Courtesy of the artist and Thomas Dane Gallery, London. Reproduced with permission.

Following Thierry de Duve's (2007) critical focus on glocalisation of contemporary arts and the corresponding predicaments of aesthetic judgement, Angela Dimitrakaki (2012: 317) suggests that the ethnographic turn in global arts risks 'the collapse of pedagogy into the consumption of [cultural, or indigenous] 'outputs', which is of course a ubiquitous feature of the post-Fordist knowledge economy.' In Dimitrakaki's discussion of the 'ethnographic turn,' the 'radical gesture' within the presupposition of art's potential as 'social document,' that is exemplified by 'participatory, postdocumentary video essay, [is] undone by its exhibition form':

the video essay tries to outsmart the exhibition by incorporating, narrating and questioning the social document in its own terms. ... But in doing so it becomes complicit in making peripheral the complex cooperative production of the experiential knowledge it stands for (Dimitrakaki 2012: 316-7).

However, the dynamic scale at work in Ataman's practice, reinforced by his rigorous formal strategies, withdraws from the 'social pragmatism' within the art world's ethnographic paradigm: the artist's pieces actively disidentify with the mark of 'social document' and addresses the spectator's experience via the unstable regional index embedded in his videographic discourse and installation form. In this respect, Ataman's Küba acts as a powerful example for the ways in which the artist actively engages with and critiques the ideologies of 'cultural value' in the ethnographic art practices. The artist's presentation of Küba-as-community/Küba-as-artwork appropriates and unsettles the inter-scalar politics of the ethnographic turn.

\section{Scaling Travel: From Expansive Selves to Expansive Communities}

The spatial dimensions implicated in Ataman's early video-portraits get more complex in his later portrayals of communities. 'How can people become communities? How are they getting organized, as a group, through a single identity? ... What do you give from yourself and what do you obtain?' asks the artist in one of 
his interviews explaining the motivations behind his forty-screen installation work Küba (2005). Here, Ataman's curiosity moves from constitutions of individual life stories and identities to constructions of communities. The shanty neighbourhood Küba, built in Tozkoparan, Istanbul, by mostly Kurdish immigrants from Eastern Anatolia in the early 1960s, becomes a curious ethnographic field for Ataman's practice due to the complex layers of phantasmatic identifications and disidentifications, belongings and unbelongings, embedded in the Küban community across time and space.

What turns Küba into a community is not any religious, ethnic or intellectual background shared by its inhabitants, but simply a strong sense of resistance and solidarity, free from any specific ideological stance or political struggle, yet protecting them against the threats of a larger society that surrounds them as misfits, and thus, forcing them to remain as such. (Baykal 2008: 71)

Not relying on any conventional identity marker, the Kübans passionately inhabit their space and ghettoise themselves. One the one hand, the community can be seen as a by-product of Turkey's state ideology operating across ethnicity, class and gender: the residents of Küba embody the margins they had been incited to and through their passionate solidarity they seem to reappropriate new forms of family and kinship. On the other hand, this immaterial belonging, not easily categorised, is also being undone by expressions of unhappiness and disappointment on screen.

Being Küban signifies 'a sense of collective disregard for authority and a group united by belonging nowhere else' (Wilkie 2011: 169). In this sense, Küba becomes 'the collective dwelling of these social outsiders and the modes of alliance and kinship through which it is sustained against complex, and often violent, challenges' (ibid: 170). Recalling also that the Kübans did not allow the artist to exhibit this work in Turkey, I would argue that there is a considerable risk and challenge for an artist to attempt to portray a community - that excessively invests in its own regional belonging and refuses to be re-presented in Turkey - to a global audience. What particularly interests me here is neither the ethical dilemma in not being able to present this work 'at home,' nor a further critical examination of what Alisa Lebow (2008: 60) regards as 'the limits of [art's] mobility' in the case of Küba. Resonating with Dimitrakaki's (2012: 317) critical focus on the paradox of 'deferral' in the institutional display, and thus the exhibition form, of ethnographic art-practice, Lebow's (2008: 64-5) discussion suggests that '[Küba's] socio-political dimension ... is significantly lost in transposition, if not translation [within the] dehistoricized context of the Western exhibition space' whose institutional ground produce further the 'neutralization of art's political effectivity' (63). What I would like to capitalise upon, however, is the ways in which the artist takes the challenge of Küba's passionate inhabitation of space and attempts to develop aesthetic strategies of depicting this will to space and formulating an ethnographic frame through an affective intimate encounter between the (intricacies of the) local and the (possibly flattening gaze of the) global. Ataman diversifies the scale of Küba in more explicit and complicated ways than he did in his earlier works: while he addresses the tension between the local and the global in the multi-screen installation form, the individualcommunal dialectic in the narrative also play a considerable role in re-figuring the work as ethnographic document. 
In the case of Küba I want to ... recreate the reality of the neighborhood through stories of individuals that go make up this community. The formula I found for this concept is to make an installation consisting of 40 talking heads, each one a Küban, from the matriarchs to the children. Each one will have a monitor allocated to him and her, and each monitor will have a chair in front of it, allowing only one viewer per monitor. By way of an installation, I intend to create a neighborhood that can travel as a whole, not just to the greater Turkish society which created Küba as its own anti-thesis, but more pointedly to major western centres where non-westerners are often accessed not as real individuals, but as role players of a greater presupposed fiction constructed for them by the international media, where Muslim implies terrorism and Africans simply embody poverty and disease. (Ataman 2006: 21)

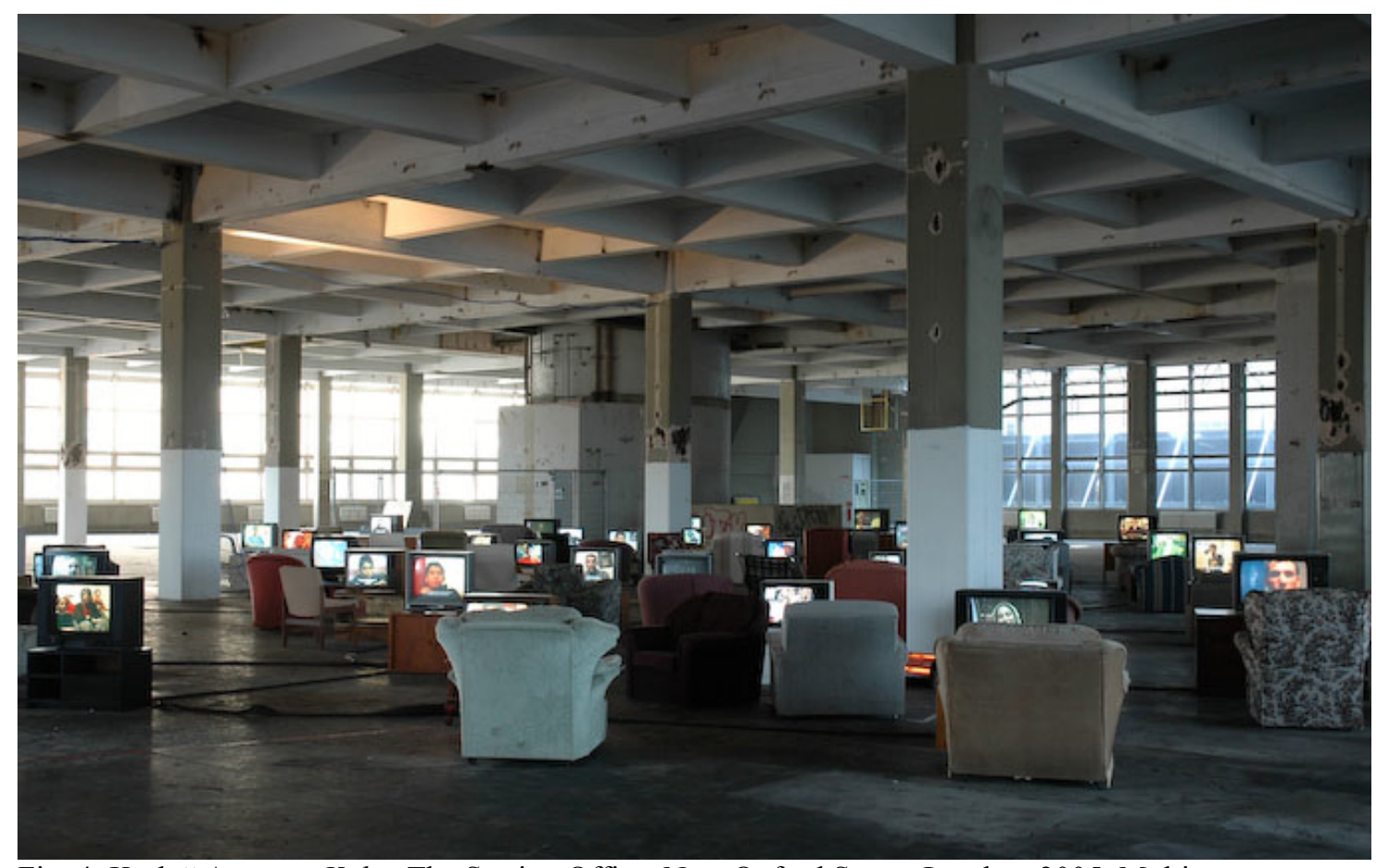

Fig. 4: Kutluğ Ataman, Küba, The Sorting Office, New Oxford Street, London, 2005. Multi-screen video installation. Commissioned and produced by Artangel. Courtesy of the artist and Thomas Dane Gallery, London. Reproduced with permission.

The community's insistence on its regional interiority turns into a performative potential in the artist's project. Not to reduce the inevitably anonymous encounter of the global art consumer with the Kübans, or Küba-as-region, to a colonising and exoticising one, Ataman not only extends the scale (to 40-screen multi-channel installation), but also creates a space with a limited access to the viewer's body: the viewer either walks by the outer circle of these 40 screens without hearing the address demanded by each talking head, or s/he chooses an available armchair, sits on it, exposes himself/herself to the corresponding screen and the talking subject, along with the cacophony of voices around the monitor, s/he looks for another available chair for another conversation: 'what is at stake here,' according to Ataman, 'is not watching, but rather a dialogue':

You join that community, listen to their stories, stroll around the monitors by 
your own free will and when you get out, you say 'I saw Küba, the work called Küba;' but in fact the work created there is the narrative construction that you yourself created as a viewer. (from Çavuş's film Kutluğ Ataman, 2011)

What makes the space of Ataman's Küba intriguing is this paradoxical level of anonymity and intimacy, which refigures the meaning of the exotic as well as the ethic in documentation and generates an inoperative ethnographic document with an impossible community:

It is from the edges of the space that the intimacy of the experience becomes clear. Küba invites its trespassing visitors, perhaps only for a short while, to make themselves at home, while always maintaining a space in which they are reminded of being out of place. (Wilkie 2011: 167)

This setting of anonymous intimacy sustains its efficacy as the exhibitionary context of video goes beyond film-as-medium and 'raises questions regarding the fundamental compatibility of the narrative film form as an ethnographic medium' (Basu 2008:104). Furthermore, the key aesthetic elements in Ataman's early artpractice, namely duration, narrative parallaxing and exhibition/installation form, function dramatically in order to undo the artwork's status as 'ethnographic document' in oscillating between different spatial registers of scale. The individual is parallaxed with the communal: to experience Küba as a community is inevitably connected to each resident's identificatory investment which does not suggest an intelligible group identity. This community cannot be easily contained, appropriated, or consumed by the global viewer as a unitary identity:

There is then a moment in the experience of Küba when you realize that you are being presented with something other than an ethnographic document, however sympathetically presented by Ataman the informant. It is that moment when you realize the difficulty of finding an appropriate critical distance, that you risk being drawn into this sea of voices but on the other hand, however indirectly, the work has the potential to return the audience's gaze. What would it be like to know the stories of these people here in this room watching this installation? Perhaps this exploration of a shantytown in Istanbul is also a reflection on our powerlessness to come up with any narratives of progress or political emancipation in which we and these "others" could participate as equals (Nash 2005: 46).

What also matters significantly, in addition to the intratextual implications of regional address in various scales, is that Küba's passionate inhabitation of space, as well as its displacement from space, is paradoxically transformed into an aesthetics of travel and transitory encounters. In other words, Küba's global travel as artwork in different exhibitionary contexts becomes a fundamental component of its parallactic selfreflexivity. As Bill Horrigan states (2005 n.p.), the artwork is treated 'from the start as a shape-shifting organism, both transient and transitory, with each presentation along its itinerary fundamentally reconstituting itself as though for the first time'.

In radically enacting 'the discrepancy between the traveling of the artwork and the residing of its subjects' and making the installation a conceptual embodiment of migration, the artist 'invites reflection on the nature of being at home in a context of 
mobility' (Wilkie 2011: 170). Furthermore, Fiona Wilkie states that the artwork functions through 'tensions of travel and home' (ibid.). According to the scholar, Küba reveals this tension

by foregrounding what might be described in conventional analytical terms as a content/form/place relationship: between what is told, how it is told, and where it is told. It is concerned with emplacement (in a neighborhood that commands strong and contradictory emotions), displacement (from that home, via the installation tour and via the narratives of escape that the work tells) and taking place (in a series of sites that themselves have intricate histories of inhabitation and movement). (Wilkie 2011: 169)

While the performative inhabitation of identity depicted in Women Who Wear Wigs suggests 'wig' as a performatively scaled site of critique, dissident subjectivity and creativity, Küba offers spaces and scapes of travel as sites of thought. In response to a question on Küba as a spatial metaphor, Ataman explains 'my Küba, the way I created it, could be anywhere'. It travels and it is 'beyond social documentation': Ataman's Küba, then, in his own words, is 'a state of mind, an idea [rather] than an address' (Ataman in Zyman 2006: 28). How, then, does such a conceptual, or conceptional, practice relate to spatiality of difference? 'To figure out a way beyond and through the impossibility of community' within site-specific art, Miwon Kwon proposes an aesthetic investment in difference via 'relational specificity' that

address[es] the uneven conditions of adjacencies and distances between one thing, one person, one place, one thought, one fragment next to another, rather than invoking equivalences via one thing after another. Only those cultural practices that have this relational sensibility can turn local encounters into long-term commitments and transform passing intimacies into indelible, unretractable social marks- so that the sequence of sites that we inhabit in our life's traversal does not become genericized into an undifferentiated serialization, one place after another. (Kwon 2002: 166)

I would like to connect such relationality, again, with Strathern's understanding of the postplural abstraction of scale in ethnography. Rather than investing in postmodern relativistic celebration of the local, Küba seems to 'scope [its] own comparison' (Holbraad \& Pederson 2009: 379) by being made a scalar figuration itself: Küba as the travelling art-work performs the migrant subject, it performs its own scalar discourse. Thus, the regional relationality that Ataman's practice constructs with the impossible communities of Küba (and Paradise) does not mark the regional as authentic, inherently resistant to and intrinsically disruptive of the global market expansion - as depicted in Kenneth Frampton's 'critical regionalism' (1983) or Edward Soja's 'postmodern geographies' (1989). On the contrary, reappropriating the exotic, the artist mimics the representational logic of the global gaze - where the regional index contracts and expands in the art-work's possible critical valencies. As can be seen in Küba's complex layers of migration, displacement and emplacement/inhabitation, the art-work enacts that which it narrates: it becomes a displaced migrant as well as a devoted inhabitant. What precisely reappropriates the regional (and the exotic) is the encounter of this aesthetic migrancy with the EuroAmerican art scene. Küba, being 'a state of mind, an idea rather than an address' becomes a scalar concept, an art of self-scaling. 


\section{'Without the Renaissance inbetween': Mesopotamian Dramaturgies}

As discussed above, Ataman's critical transregionalism, suggesting a multitude of voices in an attempt to bend 'the flattening gaze of the global' and to respond to the ethnographic turn performatively, has implicated a dynamic, relational scale of (discursive) locations within its parallaxed narratives of identity and space. In this sense, what his latest series of works - entitled Mesopotamian Dramaturgies (20092012) - demonstrates is that the artist's work as a whole, as a theoretical object, had always incorporated a critical relation to the constructions of regions, geography and history. What was implicitly being performed in early works becomes a central statement in later works. These artworks strengthen this accent on geography, history and indigenous modernities under global flux. While the depiction of community in $K \ddot{u} b a$ is performed through complex layers of installation form and a rhetoric of embodied travel in order to formulate a de-colonising, self-scaling ethnographic encounter with the global art consumer beyond documentation, the politics of region/ality in Mesopotamian Dramaturgies gains an additional aesthetic layer of selfreflexivity where the mediality becomes a parallactic component in presenting nonwestern alterity. Predicaments of mediating difference to the international art scene including the global art consumer became Ataman's revised question.

Hal Foster's proposal in response to the ethnographic turn in arts, the proposal of 'a parallactic work that attempts to frame the framer as he or she frames the other,' (1996: 203) is, as mentioned earlier, dramatically at play in Ataman's art-practice especially in Mesopotamian Dramaturgies. While 'the framer' to be critically 'framed' in Foster's critique refers to authorship and the artist's agency, Ataman's use of classical and modern Western art media, ranging from photography and video to columns and the Renaissance frescos, addresses failures of cultural translation and creative potentials of those failures in articulating the modern of the other, which in turn frames the moderniser-as-framer, or the viewer-as-framer, and/or any embodiment of the 'globalising' Western gaze as framer - as $\mathrm{s} / \mathrm{he}$ frames the other.

Frame (2009) (Fig. 5) is the central work of Mesopotamian Dramaturgies, which presents the falsity of the modernising force, the gatekeepers - as it were - of the identity-making, history-writing dramaturgies of Anatolia within Mesopotamia. The photograph in the artwork, which Ataman had found in his family album, is the key inspiration for the whole series. Frame shows its viewer this photograph of military members with the pasha in the front centre, where the logic of military hierarchy in Turkey not only dominates but also contradicts the logic of photographic framing. As Cristiana Perella (2010: 24) also suggests, in Frame,

the modernity of the photographic medium runs up against an archaic idea of representation, a structure of the image that is still Byzantine in character, in which the space organized on the basis of abstract, hierarchic rules, and the general, the pasha, occupies the center of the scene while the lower ranks around him are crudely pushed aside.

The piece in its creative enactment of a failure, of the failed ideal of modernisation, shows its viewer the paradox of locality and modernity, and the ways in which 'a nation forms and stages its own narrative' of nationness and modernity (ibid: 22). The 
false logic in Frame, according to Ataman, allegorises the 'lack of the experience of Renaissance' (Ataman in Çavuş's KA 2011): it is a photograph lacking the critical originary cultural point in photography's own history. What particularly interests the artist here is the creative tensions in these failed translations that 'create their own versions of modernity' (ibid.). Regionality confronts the global gaze in Ataman's selfregioning discourse.

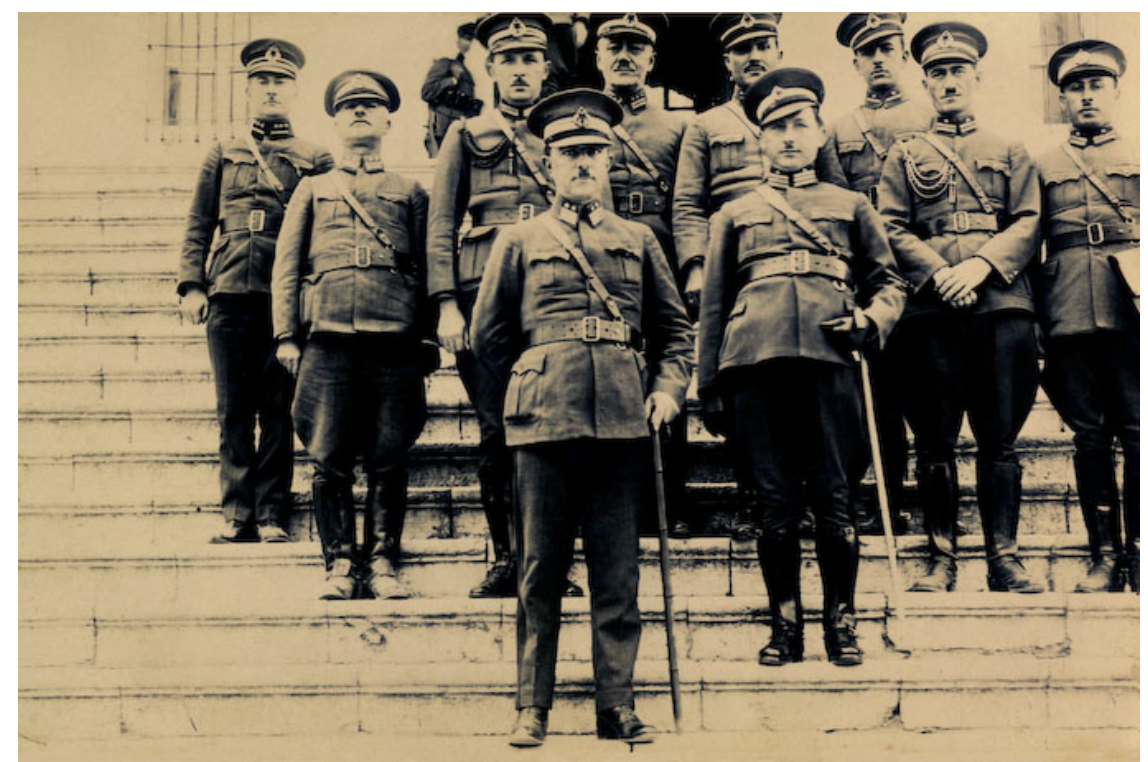

Fig. 5: Kutluğ Ataman, Frame from Mesopotomian Dramaturgies series, 2009.

Courtesy of the artist and Thomas Dane Gallery, London. Reproduced with permission.

A similar treatment of medium as narrative motor is at play in Column (2009) (Fig. $6.1 \& 6.2$ ) and Dome (2009) (Fig. 7.1, 7.2 \& 7.3). In the screen-based video-sculpture Column, television monitors are piled upon one another to form a monument where each screen contains a still face of an inhabitant of southeastern Anatolia, Erzincan, looking at the viewer. Indeed, the indexical status of the piece as monument accommodates a performative irony. Influenced by Trajan's Column (La Colonna Traiana) in Rome during his residency, Ataman cites and appropriates the narrative and structural logic of a column in order to create

a monument to people who do not have the voice to broadcast their victories, a monument to people whose only victory is the fact that they existed ... a monument which becomes a monument without being a monument in Western classical sense. (Ataman in Çavus 2011).

Like the residents of Küba, the Kurdish actors of Column direct their gaze to the viewer and perform their silenced but enduring inhabitation of Anatolia. In Dome (2009), however, Ataman presents his viewer with images of Turkey's youth 'flying in the sky almost like angels' (Ataman in Çavus 2011). The artist creates 'a contemporary version of the frescoes on the vaults of Renaissance churches' (Perella 2010: 28) by a screen projection covering the ceiling while these young men are posing and showing the viewer their cell phones. The parodic component of the piece, supplemented by these men's posing in fake D\&G clothes with mobile phones connoting and mocking the idea of modernisation and progress (reminding one of Atatürk's words, 'The Future is in the Sky / Istikbal göklerdedir'), is made tangible by means of the exhibition setting. While still images of the inhabitants of Anatolia in 
Column face the generals of Frame in the exhibition space of MAXXI in Rome, the youth in Column appear to escape to the sky, which, in Ataman's cunning exhibition setting, enacts what the founder of the Turkish Republic had once promised them as 'future'.

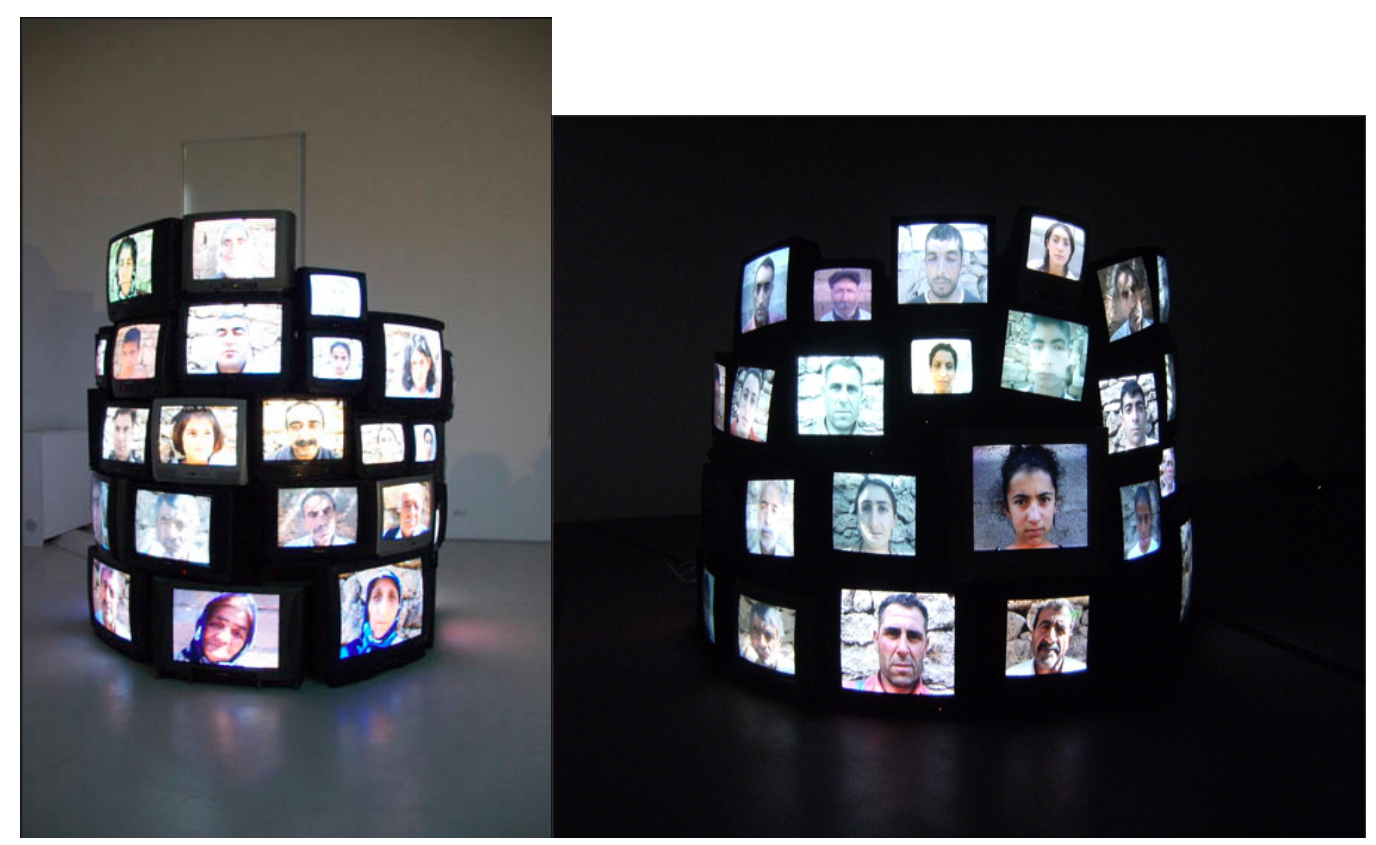

Fig. 6.1 \& 6.2: Kutluğ Ataman, Column from Mesopotomian Dramaturgies series, 2009. Courtesy of the artist and Thomas Dane Gallery, London. Reproduced with permission.

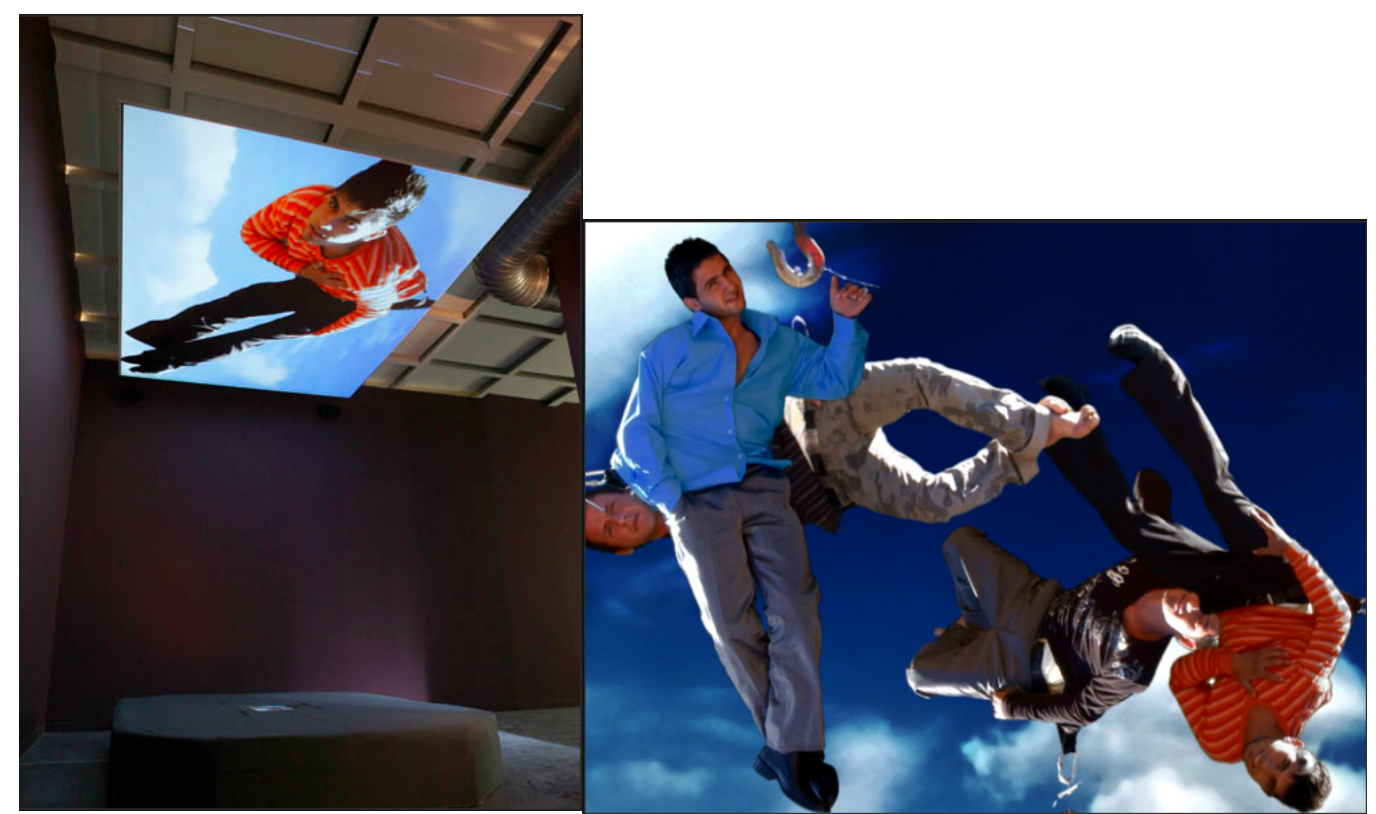




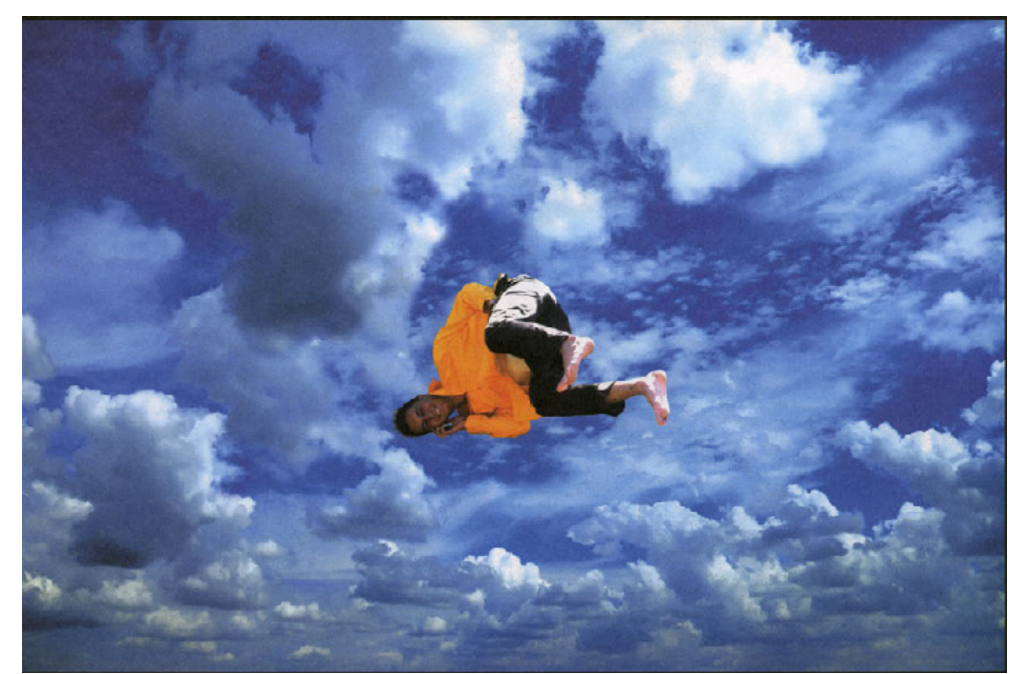

Fig. 7.1, 7.2 \& 7.3: Kutluğ Ataman, Dome from Mesopotomian Dramaturgies series, 2009. Courtesy of the artist and Thomas Dane Gallery, London. Reproduced with permission.

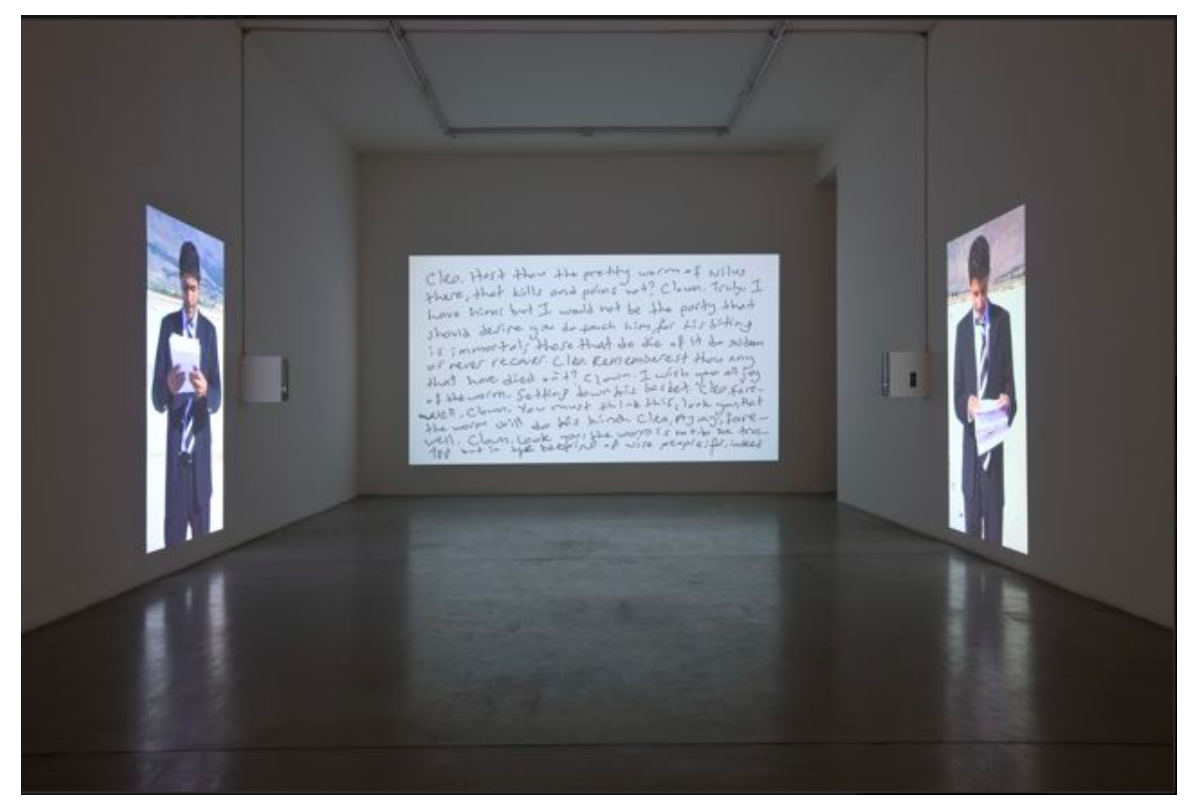

Fig. 8: Kutluğ Ataman, English as a Second Language and The Complete Works of William Shakespeare from Mesopotomian Dramaturgies series, 2009. Courtesy of the artist and Thomas Dane Gallery, London. Reproduced with permission.

The two works of the series, English as a Second Language and The Complete Works of William Shakespeare (Fig. 8), further question modernity as a phenomenon of failed translation in making the failure a performative creative act. Whereas the former presents Turkish youth reading out aloud the rhymes of Edward Lear, the latter is a four-and-a-half minute projection of the handwritten transcription of all of Shakespeare's plays. While the former treats English as lingua franca of the modern and '[mocks] the illusory universality of globalization' (Perella 2010:24), the latter performs an extratextual translation, or perhaps a cross-cultural transfiguration, from text to calligraphic image. In other words, what Ataman already explored in Frame, Column and Dome by mediating cultural alterity via originally western art forms in order to demonstrate paradoxes of translation, is being literalised in English as a Second Language and The Complete Works. While these two works comment critically on the republican vision of modernity in Turkey as adaptation, or hegemonic translation from above, they also demonstrate the diverse transformative potentials in 
the very failure of that direct transfer, or that of Occidentalist mimicry. Appropriations of the Occident in non-Western geographies, according to Meltem Ahıska, leads to 'a series of splits':

In Turkey, projection, in its double process, figures in the conception of "the people" on the one hand, and in the conception of "the West" on the other. Members of the national elite constituted their identity through a projection of the West in affirming their construction of a modern society. They organized the desire to be modern around the marker of "the West," which they claimed to possess. By doing this they introjected the imagined nation into their subjectivity. But they displaced what is disturbing for them, such as the threatening power of the West, by assuming a guardian role that modernizes but at the same time protects the "less civilized" and "infantile" population from the "dangers of too much Westernization." The virtual viewpoint of the West, which is the product of double projection, oscillates between recognition and rejection, leading to a series of splits. (Ahiska 2003: 366).

In this respect, what seems to be revealed in Ataman's strategic treatment of the region Mesopotamia as concept, as a 'space of tension,' 'a collapse of meaning' (Ataman in Perella 2011: 16) that have hitherto implicated diverse scales of manipulation and oppression (as well as decline and progress) across times, is the complex trafficking of gazes and contemporary projections of the Orient and the Occident within the phantasmatic investments in regions. By 'dramaturgies,' the artist alludes to constructions of history and geography in 'unframing and reframing the historical location of subjects' (Rogoff 2010: 54). Ataman's address in 'territorial affinit[ies] rather than belonging[s]' (ibid.) locates the viewer, the global art enthusiast, within its discursive framework. In my opinion, this affinity, or what Kwon suggested as 'relational specificity,' still bears a crucial potential for the art critic, to critically re-evaluate the ethnographic turns in global art market and its politics of scaling.

This discussion concentrating on Ataman's art practice targeted the critical possibilities of interpreting the artist's diverse implications of scale and regionality throughout his oeuvre, and re-framing his approach with reference to Hal Foster's critique of 'the artist as ethnographer'. Ataman's work engages with the scalar (global/local) dynamics in artistic production in a complex and playful fashion. The artist's 'parallactic self-reflexivity' (to quote Foster's expression again) creates dynamic and versatile visualities, images of global travel, that invite, lure, and trick the 'receiver' or any potential 'framer' exposed to the artwork, and constantly attempt to interrupt the ideological process of 'framing' the content spatially. Dramatically at work here is an ethic of alterity, which, as Mark Nash (2005: 47-8) put aptly, 'proposes an integration or reincorporation of difference ... instead of reinforcing an ego defensively against difference.'

\section{Acknowledgements:}

I would like to thank Louisa Adam from Thomas Dane Gallery, London, for her hospitality in providing me with a study space at the gallery and for granting me permission to use their archive material. 


\section{Bibliography:}

Ahiska, M. 2003. Occidentalism: The Historical Fantasy of the Modern. South Atlantic Quarterly 102(2/3): 351-379.

Anton, S. 2003. A thousand words: Kutluğ Ataman talks about $1+1=1$. Artforum 41(6): 116-7.

Ataman, K. 2006. What is Küba? In Küba: Journey Against the Current, ed. Gabrielle Cram and Daniela Zyman, 20-21. Thyssen-Bornemisza Art Contemporary: Vienna in collaboration with Springer: New York.

Basu, P. 2008. Reframing Ethnographic Film. In Rethinking Documentary: New Perspectives and Practices, ed. T. Austin and W. de Jong, 94-106. Maidenhead: Open University Press.

Baykal, E. 2008. Kutluğ Ataman: Sen Zaten Kendini Anlat! [Kutluğ Ataman: You Tell About Yourself Anyway!]. Istanbul: YKY.

Clifford, J. 2002. An Ethnographer in the Field (Interview). In Site-Specificity: The Ethnographic Turn, ed. Alex Coles, 52-71. London: Black Dog Publishing.

Çakırlar, C. 2011. Queer Art of Parallaxed Document: Visual Discourse of Docudrag in Kutluğ Ataman's Never My Soul!. Screen 52(3): 358-375.

De Duve, T. 2007. The Glocal and the Singuniversal. Third Text 21(6): 681-88.

Demos, T.J. 2010. Kutluğ Ataman: The Art of Storytelling. In Kutluğ Ataman: The Enemy Inside Me, ed. B. Temel, 30-37. Istanbul: Istanbul Museum of Modern Art.

Demos, T.J. 2013. The Migrant Image: The Art and Politics of Documentary during Global Crisis. Durham \& London: Duke University Press.

Dimitrakaki, A. 2012. Art, Globalization and the Exhibition Form. Third Text 26(3): 305-319.

Foster, H. 1996. The Return of the Real: the Avant-Garde at the End of the Century. Cambridge, MA: MIT Press.

Frampton, K. 1983. Towards a Critical Regionalism: Six Points for an Architecture of Resistance. In The Anti-Aesthetic: Essays on Postmodern Culture, ed. H. Foster, 1631. Port Townsend, WA: Bay Press.

Gade, R. 2003. Talk \& show - Kutluğ Ataman and oral visuality. In Kutluğ Ataman Long Streams (exhibition catalgue), 6-11. London: Serpentine Gallery, 2003.

Gopinath, G. 2008. Queer Regions: Locating Lesbians in Sancharram. A Companion to Lesbian, Gay, Bisexual, Transgender and Queer Studies, ed. G. Haggerty and M. McGerry, 341-54. Blackwell: Oxford. 
Gibson-Graham, J.K. 2002. Beyond Global vs. Local: Economic Politics Outside the Binary Frame. In Geographies of Power: Placing Scale, ed. A. Herod and M. W. Wright, 25-60. Oxford: Blackwell.

Herod, A. 2011. Scale. London and New York: Routledge.

Holbraad, M. and M.A. Pedersen. 2009. Planet M: The intense abstraction of Marilyn Strathern. Anthropological Theory 9(4): 371-394.

Honigman, A. F. 2004. What the structure defines: an interview with Kutluğ Ataman. Art Journal 63(1): 79-86.

Horrigan, B. 2005. Introduction: Küba, Si! In Küba, Kutluğ Ataman. London: Artangel; Pittsburgh: Carnegie Museum of Art; New York: Lehmann Maupin Gallery; Sydney: Museum of Contemporary Art; Vienna: T-B A21; Stuttgart: Theater der Welt.

Kwon, M. 2002. One Place after Another: Site-Specific Art and Locational Identity. London: MIT Press.

Lebow, A. 2008. Worldwide wigs: Kutluğ Ataman and the global art documentary. Arab Studies Journal 15-16(2-1): 57-82.

Nash, M. 2005. Kutluğ Ataman's experiments with truth. In Kutluğ Ataman: Perfect Strangers, exhibition catalogue, 42-48. Sydney: Museum of Contemporary Art.

Perella, C. 2010. The Future is in the Sky. Kutlug Ataman, Mesopotamian Dramaturgies: Catalogo della mostra (exhibition catalogue), 16-31. Roma: Mondadori Electa.

Rogoff, I. 2000. Terra Infirma: Geography's Visual Culture. London and New York: Routledge.

Rogoff, I. 2009. De-regulation: with the work of Kutluğ Ataman, Third Text 23(2): $165-79$.

Rogoff, I. 2010. Regional Imaginings. In Unleashed: Contemporary Art from Turkey, ed. H. Amirsadeghi, 48-55. London: TransGlobe Publishing.

Soja, E. 1989. Postmodern Geographies: The Reassertion of Space in Critical Social Theory. London: Verso.

Strathern, M. 2004 [1991]. Partial Connections. Updated Edition. Walnut Creek: Altamira Press.

Wilkie, F. 2011. The Armchair Traveler: Küba on the Move. The Drama Review 55(3):164-173.

Zyman, D. 2006. Life as a Metaphor (In Conversation with Kutluğ Ataman). In Küba: Journey Against the Current, ed. Thyssen-Bornemisza Art Contemporary, 26-31. 
Springer: New York.

\section{Filmography:}

Kutlŭ Ataman. DVD. 2011. Directed by Metin Çavuş, The Institute for Readjustment of Clocks. 